\title{
Assessing Migratory Double Breeding Through Complementary Specimen Densities and Breeding Records
}

\author{
Author(s): Sievert Rohwer, Vanya G. Rohwer, A. Townsend Peterson, Adolfo G. Navarro-Sigüenza and \\ Philina English \\ Source: The Condor, 114(1):1-14. 2012. \\ Published By: Cooper Ornithological Society \\ URL: http://www.bioone.org/doi/full/10.1525/cond.2012.110064
}

BioOne (www.bioone.org) is a nonprofit, online aggregation of core research in the biological, ecological, and environmental sciences. BioOne provides a sustainable online platform for over 170 journals and books published by nonprofit societies, associations, museums, institutions, and presses.

Your use of this PDF, the BioOne Web site, and all posted and associated content indicates your acceptance of BioOne's Terms of Use, available at www.bioone.org/page/terms_of_use.

Usage of BioOne content is strictly limited to personal, educational, and non-commercial use. Commercial inquiries or rights and permissions requests should be directed to the individual publisher as copyright holder. 


\title{
RESEARCH PAPERS
}

The Condor 114(1):1-14

(C) The Cooper Ornithological Society 2012

\section{ASSESSING MIGRATORY DOUBLE BREEDING THROUGH COMPLEMENTARY SPECIMEN DENSITIES AND BREEDING RECORDS}

\author{
Sievert Rohwer ${ }^{1,5}$, Vanya G. Rohwer ${ }^{2}$, A. Townsend Peterson ${ }^{3}$, Adolfo G. Navarro-Sigüenza $^{4}$, \\ AND Philina ENGLish ${ }^{2}$ \\ ${ }^{1}$ Burke Museum and Department of Biology, University of Washington, Seattle, WA 98195-1800 \\ ${ }^{2}$ Department of Biology, Queen's University, Kingston, ON K7L3N6, Canada \\ ${ }^{3}$ Natural History Museum \& Biodiversity Research Center, University of Kansas, Lawrence, KS 66045 \\ ${ }^{4}$ Museo de Zoología, Departamento de Biología Evolutiva, Facultad de Ciencias, Universidad Nacional Autónoma de México, \\ Apartado Postal 70-399, México, D. F. 04510, Mexico
}

\begin{abstract}
We re-evaluate the plausibility that five species of birds that breed in late summer in northwestern Mexico are migratory double breeders that first bred earlier in the same season to the north. We use data aggregated from scientific collections to generate abundance indices that adjust counts of specimens in collections by collecting effort, which we measure as the number of passerines collected in the same region and time period as the species of interest. Our abundance indices generally show displaced phenologies, such that presumed double breeders arrive and breed early in the north, then later in northwestern Mexico. We also compare breeding records for these regions, but these records could not be corrected for effort. Our phenologies suggest that the breeding populations of the Yellow-billed Cuckoo (Coccyzus americanus) from the western U.S. and northwestern Mexico may be derived from birds that bred earlier in eastern North America. Similarly, Orchard Orioles (Icterus spurius) breeding in late summer in northwestern Mexico and on the Mexican plateau may be derived from birds that attempted to breed earlier in North America. Our abundance indices and other new data suggest migratory double breeding is less likely in the Hooded Oriole (I. cucullatus) and probably not occurring in the Yellow-breasted Chat (Icteria virens) and Cassin's Vireo (Vireo cassinii).
\end{abstract}

Key words: $\quad$ abundance index, breeding phenology, collecting effort, migratory double breeding, northwestern Mexico.

\section{Evaluando la Reproducción Doble Migratoria a través de Densidades de Especímenes Complementarias y Registros Reproductivos}

Resumen. Reevaluamos la posibilidad de que cinco especies de aves que se reproducen al final del verano en el noroeste de México son reproductores dobles migratorios que anidan primero más temprano en la misma estación más al norte. Empleamos datos agregados provenientes de colecciones científicas para generar índices de abundancia que ajustan el conteo de especímenes en las colecciones por el esfuerzo de colecta, el cual medimos como el número de paserinos colectados en la misma región y período de tiempo que la especie de interés. Nuestros índices de abundancia generalmente muestran fenologías desplazadas, de modo que los sospechosos de ser reproductores dobles llegan y se reproducen temprano en el norte y más tarde en el noroeste de México. También comparamos los registros reproductivos de estas regiones, pero estos registros no pudieron ser corregidos por el esfuerzo. Nuestras fenologías sugieren que las poblaciones reproductivas de Coccyzus americanus del oeste de EEUU y del noroeste de México pueden derivarse de aves que crían más temprano en el este de América del Norte. De modo similar, los individuos de Icterus spurius que se reproducen al final del verano en el noroeste de México y en el Altiplano Mexicano pueden derivarse de aves que intentaron criar más temprano en Norteamérica. Nuestros índices de abundancia y otros datos nuevos sugieren que la doble reproducción migratoria es menos probable en I. cucullatus y probablemente no ocurre en Icteria virens ni en Vireo cassinii.

Manuscript received 3 May 2011; accepted 5 August 2011.

${ }^{5}$ E-mail: rohwer@uw.edu

The Condor, Vol. 114, Number 1, pages 1-14. ISSN 0010-5422, electronic ISSN 1938-5422. (C 2012 by The Cooper Ornithological Society. All rights reserved. Please direct all requests for permission to photocopy or reproduce article content through the University of California Press's Rights and Permissions website, http://www.ucpressjournals.com/ reprintInfo.asp. DOI: 10.1525/cond.2012.110064 


\section{INTRODUCTION}

Rohwer et al. (2009a) recently suggested that five species of North American birds are migratory double breeders. Analyses of stable isotopes suggest that some Yellow-billed Cuckoos (Coccyzus americanus), Cassin's Vireos (Vireo cassinii), Yellow-breasted Chats (Icteria virens), Orchard Orioles (Icterus spurius), and Hooded Orioles (I. cucullatus) breed in northwestern Mexico in late summer after an earlier bout of breeding in the same summer in the U.S. or Canada. Latesummer breeding in northwestern Mexico is supported by a food flush generated by monsoon rains that deliver most of the annual precipitation to this region from July to September (Adams and Comrie 1997, Comrie and Glenn 1998).

Migratory double breeding is sufficiently novel that we further explore the plausibility of it being real for these five species. New data and methods marshaled here involve development of abundance indices, based on collection data, that can be used to evaluate the offset on phenology in abundance and nesting that should follow if migratory double breeding is real. Our abundance index, formally defined below, adjusts counts of specimens for variation in collecting effort, which we measure as total passerines collected in the same region and time period. The breeding phenologies of species posited to be migratory double breeders should be displaced, such that they arrive, nest, and depart from their first breeding area before doing so in their second breeding area. We also reexamine the subspecific identity of Vireo cassinii from Baja California Sur (BCS) and the isotope values that led to many Cassin's Vireos and Hooded Orioles from BCS being classified as migratory double breeders. Finally, we present a short summary of our first June field work in Sinaloa, which revealed June breeding by Yellow-breasted Chats and Orchard Orioles. Our general conclusion is that migratory double breeding remains plausible for the Yellow-billed Cuckoo and Orchard Oriole, possible for the Hooded Oriole, but unlikely for the Yellowbreasted Chat and Cassin's Vireo.

\section{METHODS}

\section{THE ABUNDANCE INDEX}

We downloaded data regarding the five species of interest and of passerines in general for computing abundance indices for birds across the U.S. and Canada from the ORNIS data portal (http://www.ornisnet.org) in June 2009. Because some institutional servers were not online when data were downloaded, we were not able to access data from all of the collections of North America. In all, our starting point was 241900 specimen records of passerines from the U.S. and Canada. We then sorted these data by state to create abundance indices appropriate to the North American breeding ranges of the five species of interest. For the Mexican states of BCS, Sinaloa, and Sonora, we used 37503 specimen records of passerines from the Atlas of Mexican Bird
Distributions database (Navarro-Sigüenza et al. 2003) to compute comparable abundance indices for the five species of interest in northwestern Mexico (Rohwer et al. 2009a). These totals include recent specimens from 2005 to 2007 that were not specifically collected for our research on migratory double breeding but exclude specimens that we collected specifically for that project. Again, we sorted records by state to create abundance indices appropriate to the area of interest in northwestern Mexico. For the breeding range of the Orchard Oriole on the Mexican Plateau (Dickerman and Warner 1962) we used 34557 records for passerines collected in this region, again from the Mexican atlas (Navarro-Sigüenza et al. 2003). We standardized all five species to records of passerines. Although the Yellow-billed Cuckoo is not a passerine, our experience is that it is collected along with and in much the same way as passerines, so such standardization is appropriate.

We calculated an abundance index (AI) for species $x_{k}$ in region and time period $r$ as

$$
A I_{k r}=10,000 \frac{x_{k r}}{\left(\sum_{j=1}^{n} x_{j r}\right)-x_{k r}},
$$

where $x_{k r}$ is number of specimens of the $k^{\text {th }}$ species collected in region and time period $r$ and $n$ is the total number of species in the group used to estimate collecting effort (all passerines, in our case). Multiplying by 10000 gives the index a reasonable scale. This abundance index corrects raw numbers for uneven seasonal and regional distribution of collecting effort. A correction for effort is needed because much early collecting was directed to describing geographic variation and, therefore, avoided late-summer specimens in worn plumage or in molt (Peterson et al. 1998, Rohwer et al. 2007).

To the right of each abundance-index graph, we plot the number of passerine specimens that had been collected throughout the year in that same region. This figure quantifies background collecting across the annual cycle and, thus, indexes the confidence we may have in the absence of records of the species of interest being due either to limited collecting or to the actual absence of that species in a particular place or time. Our graphs of total passerines also provide data needed to assess the effect on the abundance index of single additional (or fewer) specimens. Neither ORNIS nor the Mexican bird atlas distinguishes adult birds from juveniles, so declines in abundance in the fall do not reflect accurately the departure of breeding adults in species in which juveniles migrate later than adults, frequent when adults migrate before molting but juveniles replace body plumage before their fall migration (Rohwer et al. 2005, Barry et al. 2009).

\section{BREEDING RECORDS}

To help assess the breeding seasons of the five potential double breeders in North America and in northwestern Mexico, we summarized the date and locality of collection for egg sets in the Western Foundation of Vertebrate Zoology (WFVZ) and the University of Washington's Burke Museum (UWBM). Because 
few egg collections are accessible electronically, we could present these records only as biweekly counts, uncorrected for collecting effort. For Mexico we also present all breeding records from our field work in northwestern Mexico in 2005, 2006, 2007, 2009, and 2010. These records are based on females that were laying or incubating when they were collected or netted and released (as indicated by enlarged or ruptured follicles or edematous brood patches; Pearson and Rohwer 1998). Because most of our field work in northwestern Mexico has been directed at studies of molt (Rohwer et al. 2005, 2007, 2009b), our only June field work was in 2010. Thus the absence of June (and earlier) nesting records in our data for northwestern Mexico does not necessarily indicate that birds are not breeding at that time. From July to September there are almost no egg sets of any of these species at WFVZ, despite the abundant nesting we discovered in these months. However, relevant specimens may exist in other egg collections not checked by us. The distribution of our netting effort from June to September in northwestern Mexico is given in Figure 1.

\section{ABUNDANCE INDICES: RESULTS AND INTERPRETATION}

\section{ORCHARD ORIOLE}

The Orchard Oriole has long puzzled ornithologists because of its exceedingly early fall migration and because it is one of few migrants from eastern North America that molts after the fall migration. Migratory double breeding may explain both of these puzzles (Rohwer et al. 2009a, 2010). Orchard Orioles begin arriving in the U.S. in April, become abundant in May, and reach their peak in relative abundance in the first two weeks of June (Fig. 2). Thereafter, they decline precipitously in abundance in late June and July. Some birds are still present in August, but many of these late migrants are likely juveniles that depart in the fall later than adults (Scharf and Kren 1996). The frequency distribution of egg dates for the U.S. and Canada peaks in May and drops nearly to zero by late June (Fig. 2). This single peak reflects the rarity of second clutches (Scharf and Kren 1996) and gives breeders from eastern North America ample time to fledge young and migrate to northwestern Mexico for a second round of breeding in July or August.

Few Orchard Orioles have been collected in Sinaloa and Sonora from November through May (Fig. 2). However, they increase slightly in relative abundance in June and then jump to high numbers in July, when we also found many nests (Fig. 2). June breeders from northwestern Mexico may represent the earliest migrants from the north that either failed in northern breeding attempts or bred successfully in the southern U.S., where laying starts in late April and early May (Scharf and Kren 1996). The offsets, both in abundance indices and in the distribution of egg dates (Fig. 2), between Canada and the U.S. and northwestern Mexico are consistent with the Orchard Oriole being a migratory double breeder (Rohwer et al. 2009a). We found no Orchard Orioles in Sinaloa in July

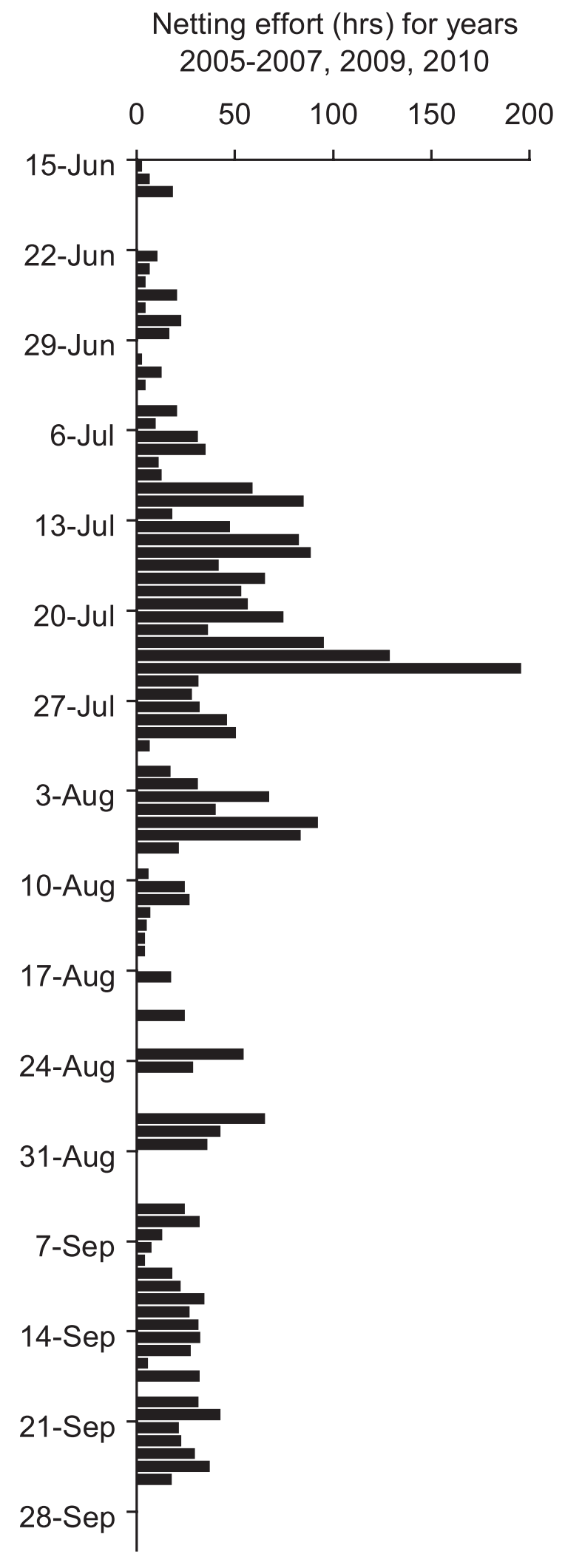

FIGURE 1. Seasonal distribution of our netting effort in northwestern Mexico, measured as summed net hours for 2005-07 and 2009-10, based on 10-m nets with four panels. 

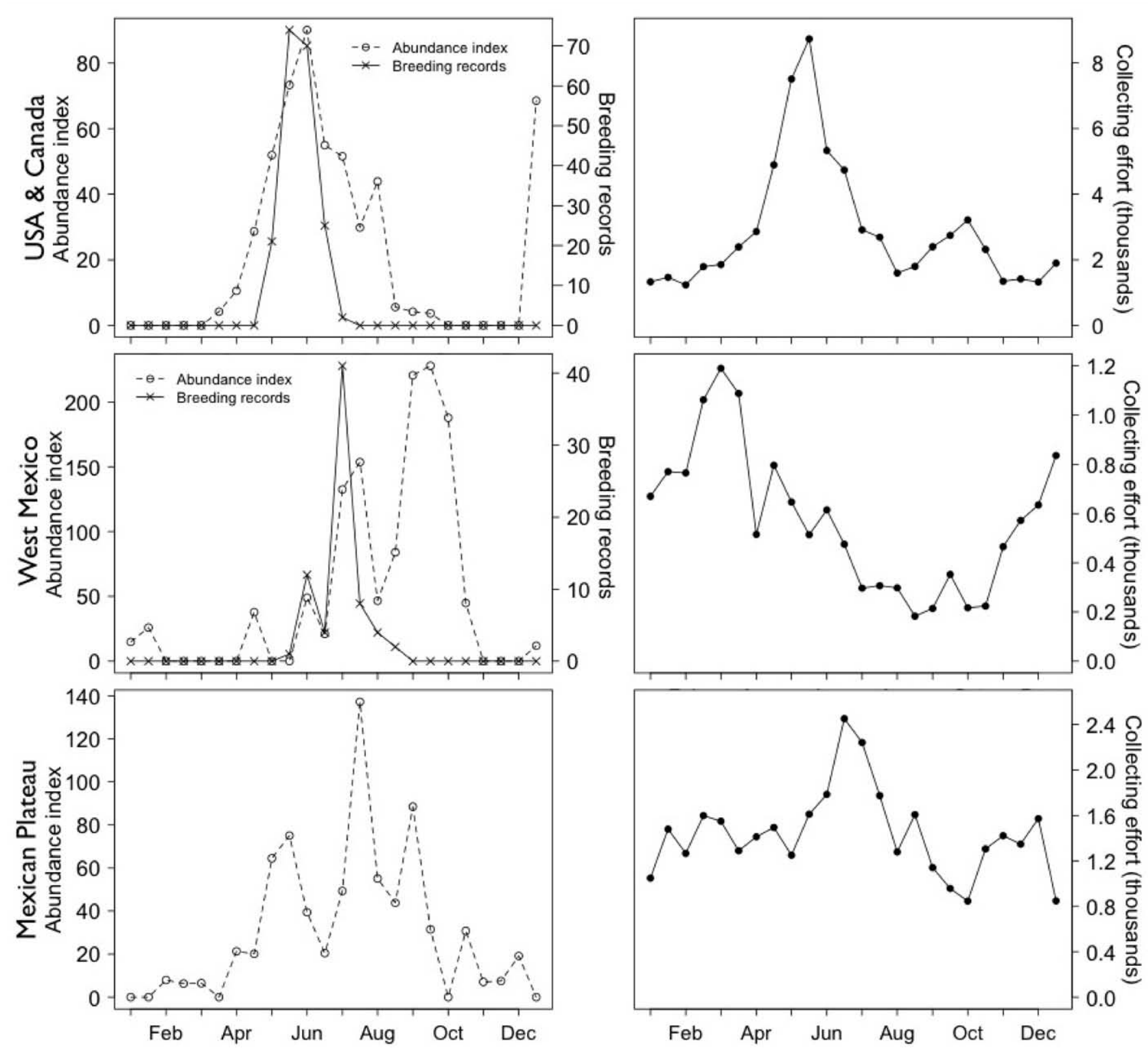

FIGURE 2. Left panels: abundance indices and counts of breeding records of the Orchard Oriole. Right panels: total passerines used to compute the corresponding abundance index. Abundance index and collecting effort included the eastern U.S. and Canada in the north, Sinaloa and Sonora in northwestern Mexico, and a number of states where this oriole breeds on the Mexican Plateau.

and August that were in heavy molt. Instead, the birds we saw breeding in July and August left the area before they molted, suggesting that they move to their wintering grounds before undergoing the post-breeding molt.

The number of July specimens of the Orchard Oriole collected in Mexico fails to illustrate the species' relative abundance in this region without correction for the minimal collecting that has characterized this month (Fig. 2). We have found the Orchard Oriole to be common in late summer in northwestern Mexico. Its abundance and breeding may have been overlooked because few collectors have worked in this region of Mexico at this time of the year. We now have many breeding specimens from late summer, but we excluded them from Figure 2 because they were collected for this project.

Dickerman and Warner (1962) described a subspecies of the Orchard Oriole (I. s. phillipsi) that breeds on the Mexican Plateau. As is often the case with continental subspecies characterized by size differences, the measurements of I. s. phillipsi overlap substantially with those of $I$. s. spurius. However, their paper raises three interesting possibilities with regard to double breeding by the Orchard Oriole: the plateau population could be an isolated and slightly differentiated breeding population, as Dickerman and Warner suggested, it could represent 
double breeders from the north, or it could be the source of the late summer breeders we found in northwestern Mexico. To address these questions we plotted abundance indices for the population of the Mexican Plateau (Dickerman and Warner 1962); again, the result is consistent with double breeding. Orchard Orioles appear in this region in April and reach an early (and low) peak in abundance in May (Fig. 2). This May peak likely represents migrants heading north because the abundance indices drop to very low values during June, when large numbers of other passerines have been collected on the plateau (Fig. 2). Then, however, the species' abundance climbs to a very high peak in July and August, suggesting an influx of breeders from the north, similar to that we found for northwestern Mexico (Fig. 2).

Data presented by Dickerman and Warner (1962) suggest that Orchard Orioles do breed on the Mexican Plateau in May at least occasionally: the type specimen of I. s. phillipsi was a male with fully enlarged testes taken on 7 May. However, the sharp June decline in the relative abundance of Orchard Oriole specimens from the plateau suggests that many of the May specimens were migrants (Fig. 2), and Dickerman and Warner (1962) noted that migrating Orchard Orioles have been collected as late as 14 May in Guerrero. Remarkably, they noted especially that this population seems to breed later than that farther north, and they listed four July nests and a nest from 13 September with four young close to fledging (Dickerman and Warner 1962). The seasonal variation in our index of Orchard Oriole abundance in this region, together with the data Dickerman and Warner (1962) presented on late breeding, is consistent with most Orchard Orioles breeding on the Mexican Plateau being migratory double breeders from the north.

The spring and fall contrast in the Orchard Oriole's relative abundance in collections from northwestern Mexico also confirms what we know about its patterns of migration. In spring the birds migrate across the Gulf of Mexico (Scharf and Kren 1996) and are largely absent from northwestern Mexico, but in fall they follow the coast west toward Mexico, rather than crossing the Gulf(Scharf and Kren 1996). Thus their relative number in collections of birds from northwestern Mexico peaks sharply in September and early October (Fig. 2). This peak seems late for a second breeding; perhaps these late migrants, which are likely to be young of the year, pass through this region to assess its potential for future late-summer breeding attempts.

We have 195 egg dates for the Orchard Oriole for Tamaulipas, the U.S., and Canada, representing spring breeding locations. Of these, only 7 from southern and central regions were so late that they appeared to be second nesting attempts. We eliminated these 7 records and then regressed day of year $(D)$ for the remaining 188 clutches on latitude $(L)$. On average, about 20 days separate initiation of nesting at the southern and northern edges of the breeding range, Tamaulipas and southern Canada, respectively $(D=115.27+1.007 L ; P<0.0001$; $\left.R^{2}=0.176\right)$. The average egg date for Orchard Orioles at $29^{\circ} \mathrm{N}$ (along the coast of the Gulf of Mexico) is day 148 (28 May).
This means that on average Orchard Orioles that breed successfully in the southern U.S., could arrive for a second breeding attempt in northwestern Mexico on day 193 (12 July); however, the earliest breeders arrive 15-20 days earlier because of the scatter in egg dates. To compute this offset we added 10 days to hatch eggs (most clutches were collected in early incubation), 14 days to fledge young, 16 days for post-fledging care, and 5 days for migration (total $=45$ days; Scharf and Kren 1996). Of course, birds that failed in attempts to breed in the U.S. could arrive considerably earlier, but birds arriving too early in northwestern Mexico would arrive before the rains.

Most of the dates of Orchard Oriole eggs we have for Sinaloa and Sonora are from the first half of July (Fig. 2). Our field effort has been substantial in July and August (Fig. 1), so the drop in frequency of nests in August probably reflects a real decline in nest initiation. Our only June field work in Sinaloa was 9-30 June 2010, during which we found 12 nests with nestlings (Fig. 2); thus June nesting is underestimated by our field observations and seems to be underestimated by specimen records as well. Of these 12 nests, for 6 we estimated first egg dates between 28 May and 4 June, similar to mean egg dates for the southern U.S. These June breeding records challenge the interpretation Orchard Orioles breeding in coastal Sinaloa have bred earlier in the north. The earliest egg date for the southern U.S. is 29 April (Florida; Scharf and Kren 1996) so, given that about 45 days are required for a successful breeding attempt and migration, the earliest that successful double breeders could start nesting in northwestern Mexico is mid June. If Orchard Orioles in northwestern Mexico are double breeders, the 12 June nests with nestlings must be by northern breeders that fail.

\section{YELLOW-BILLED CUCKOO}

We treat this species next because migratory double breeding is a new potential explanation for its declining numbers. Breeding populations in the western U.S. have collapsed in the past few decades, and eastern populations have declined significantly (Gaines and Laymon 1984, Laymon and Halterman 1987, Hughes 1999, Sauer et al. 2008). Interestingly, our abundance indices make the novel suggestion that Yellow-billed Cuckoos breeding in the western U.S. may have the same source as the late-summer breeders that we studied in northwestern Mexico.

Although Rohwer et al. (2009a, 2010) suggested that the decline in the western population of the Yellow-billed Cuckoo might be due to the recent conversion of most coastal thorn forest in northwestern Mexico to industrial farming, which has eliminated most habitat for second breeding in southern Sonora and coastal Sinaloa, our abundance indices for this species challenge this suggestion. In Figure 3 we present abundance indices and egg dates for the cuckoo from the eastern U.S. and Canada. Both relative numbers of skins in collections and numbers of egg dates increase rapidly in May to a peak in June, followed by a decline in relative abundance through late July. Then, in early August there is a peak in numbers, followed by a 
decline through fall and winter. The peak in the first two weeks of August is difficult to interpret but may represent young birds beginning to move and becoming conspicuous to collectors. A few birds winter in the southern states, as indicated by the December-March specimen records.

The earliest Yellow-billed Cuckoos collected in the Mexican states of BCS, Sinaloa, and Sonora are in the first two weeks of June, and relative numbers in these states increase through all of June and July (Fig. 3). These data clearly suggest that cuckoos are absent or, at best, present in very low numbers in northwestern Mexico through spring and early summer, times when they are breeding in eastern
North America. The displacement in both abundance indices and egg-date frequencies for these two regions suggests that cuckoos from eastern North America could be moving to northwestern Mexico for a second round of breeding. Furthermore, breeding records for northwestern Mexico from July and August are late enough to represent second breeding by Yellow-billed Cuckoos that had fledged young earlier in that same season in eastern North America, where laying starts in May. The time from egg laying to fledging is extremely rapid, requiring only 17 days; young begin to fly at 21 days, but the duration of parental care after they fly seems unknown (Hughes 1999). Eastern populations migrate to

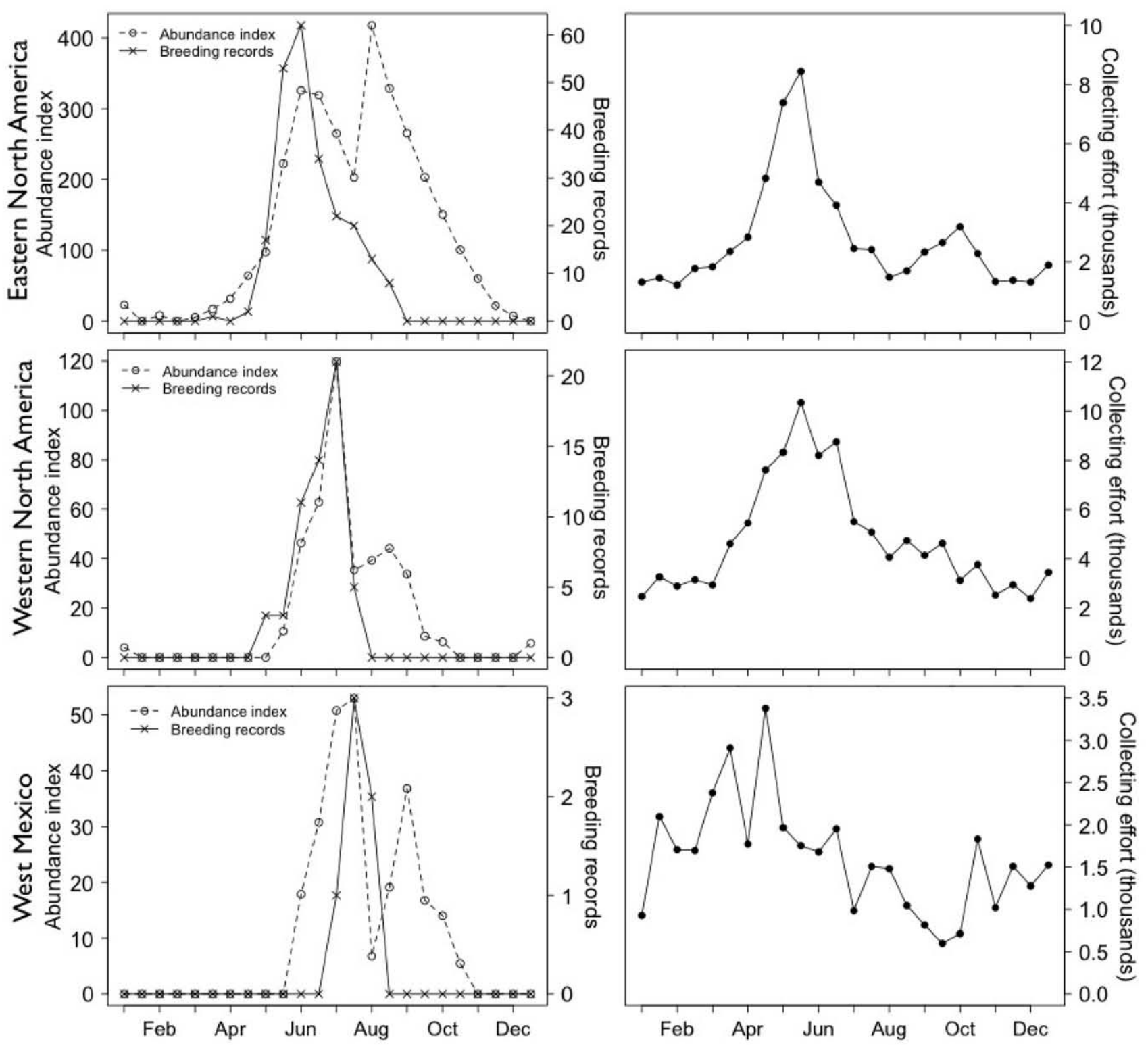

FIGURE 3. Left panels: abundance indices and counts of breeding records of the Yellow-billed Cuckoo. Right panels: total passerines used to compute the corresponding abundance index. Abundance index and collecting effort included the eastern U.S. and Canada for the east, the western U.S. and Canada for the west, and Baja California Sur, Sinaloa, and Sonora for northwestern Mexico. 
South America via both Central America and the West Indies (Hughes 1999), so continental migrants could stop to breed in Mexico in late summer.

The situation is much less clear when we compare the cuckoo's abundance indices and egg dates for northwestern Mexico with those for the western U.S. and Canada (Fig. 3). The seasonal change in the abundance index for Yellow-billed Cuckoos collected in western North America is surprisingly similar to that for cuckoos collected in northwestern Mexico. In the west, Yellow-billed Cuckoos historically became common in June and July and then declined precipitously in relative abundance in the last two weeks of July (Hughes 1999). One explanation for this similarity and for the two western abundance indices being displaced to later in the summer than that for eastern North America is that both the western U.S. and the northwestern Mexican breeding population are derived from birds that are moving into these areas from eastern North America for a second breeding. In western North America transients continue to be recorded to mid-July (Hughes 1999). Alternatively, it is possible that western U.S. breeders migrate very late and that their late arrival on the breeding grounds is instead related to different climatic conditions in the west. Geolocaters could distinguish these alternatives (Stutchbury et al. 2009).

We were surprised that the Yellow-billed Cuckoo's arrival and breeding times in western North America and northwestern Mexico were not displaced. Thus a linkage between these breeding populations is unlikely to be the cause for the cuckoo's decline in the west (Rohwer et al. 2009a, 2010) because the abundance indices and egg date distributions are not displaced enough to suggest that western North American breeders are the primary source of late-summer breeders in northwestern Mexico (Fig. 3). The alternative, that cuckoos move from eastern into western North America to breed again in late summer, would explain why R. C. Fleischer et al. (unpubl. data) found no differences between 26 eastern and 40 western cuckoos from the U.S. breeding population in the control region and ATP8 of the mitochondria. Pruett et al. (2001) did find differences between these populations but sequenced cytochrome $b$ from only five western and three eastern cuckoos, and Fleischer et al. (unpubl. data) were not able to replicate their results.

\section{HOODED ORIOLE}

Within the U.S., this species has populations breeding in southern Texas and the southwest, distinguishable by plumage (Hughes 1999). Hooded Orioles that breed in northwestern Mexico belong to the western plumage group, so we have excluded Texas records of skins and egg sets from this account. The Hooded Oriole breeds throughout the Baja California Peninsula, and we found it nesting in abundance in July and August at many sites in BCS, not only in towns, where it was the commonest bird we encountered, but also in palms and in the palm thatch of traditional roofs away from towns. Nine of the 13 specimens Rohwer et al. (2009a) examined for isotopes seemed to have bred earlier to the north; most were collected in BCS. In Sinaloa and Sonora we found the Hooded Oriole to breed uncommonly in late summer, so we treat only BCS populations of this species here.

In California, Arizona, and northern Baja California, Hooded Orioles become common in mid-March and remain abundant through early July, after which there is a general decline in relative numbers in collections until late September (Fig. 4). Adults depart the U.S. before undergoing the postbreeding molt (Rohwer et al. 2005). Unlike those of the Orchard Oriole, the earliest eggs of the Hooded Oriole in the U.S. are laid about a full month after the spring arrival (Fig. 4). Egg sets from California and Arizona occur in collections in about equally high numbers from early May through mid June and then decline sharply to almost zero by late July.

In BCS the peak arrival of Hooded Orioles is mid-to-late April, about a month later than in the U.S. (Fig. 4). After the strong late-April peak in relative abundance, specimen records decline to zero or near zero from late June through late July. Then numbers climb again for the month of August. Although we found Hooded Orioles breeding abundantly in July and August in many places in BCS, only 2 of the 40 egg sets we examined from BCS were collected in July or August; both at Santa Anita on 25 July 1896; all others were collected in April (4), May (23), and June (11). Apparently, this species has largely been overlooked as a late-summer breeder in BCS. As in the U.S., the peak count of egg dates from BCS follows the species' arrival by about a month, then drops to zero for the first two weeks of July. The second peak of nesting in Figure 4 mostly represents our nest records from BCS (except for the two late-July sets at the WFVZ). Hooded Orioles frequently nest very high in palms, so we could not check the contents of most of the nests we observed, but we collected several laying females in BCS in August (Rohwer et al. 2009a).

At least in part, the August peak in relative numbers of Hooded Oriole skins and nest counts in BCS could represent birds that had bred earlier in the north. Birds breeding during the peak period of nesting in California and Arizona (early May through mid-June; Fig. 4) could easily breed again in BCS in about 45 days, counting 10 days to finish incubation (most sets were fresh when collected), 14 days to fledge, 16 days of post-fledging care, and 5 days to fatten and migrate; these figures are estimated from data for the Orchard Oriole because such data have not been published for the Hooded Oriole (Pleasants and Albano 2001). This calculation suggests that second-breeding adults from the U.S. should arrive in BCS from late June through the end of July, consistent with the late July and August breeding we found in BCS. However, it is also possible that late-summer breeding is a response to the summer rains by local adults that bred earlier in that same summer in BCS (Schondube et al. 2003) and that migratory double breeding is lacking in the Hooded Oriole.

\section{YELLOW-BREASTED CHAT}

Chats from eastern and western North America can be distinguished by details of their facial pattern (Sibley 2000); 

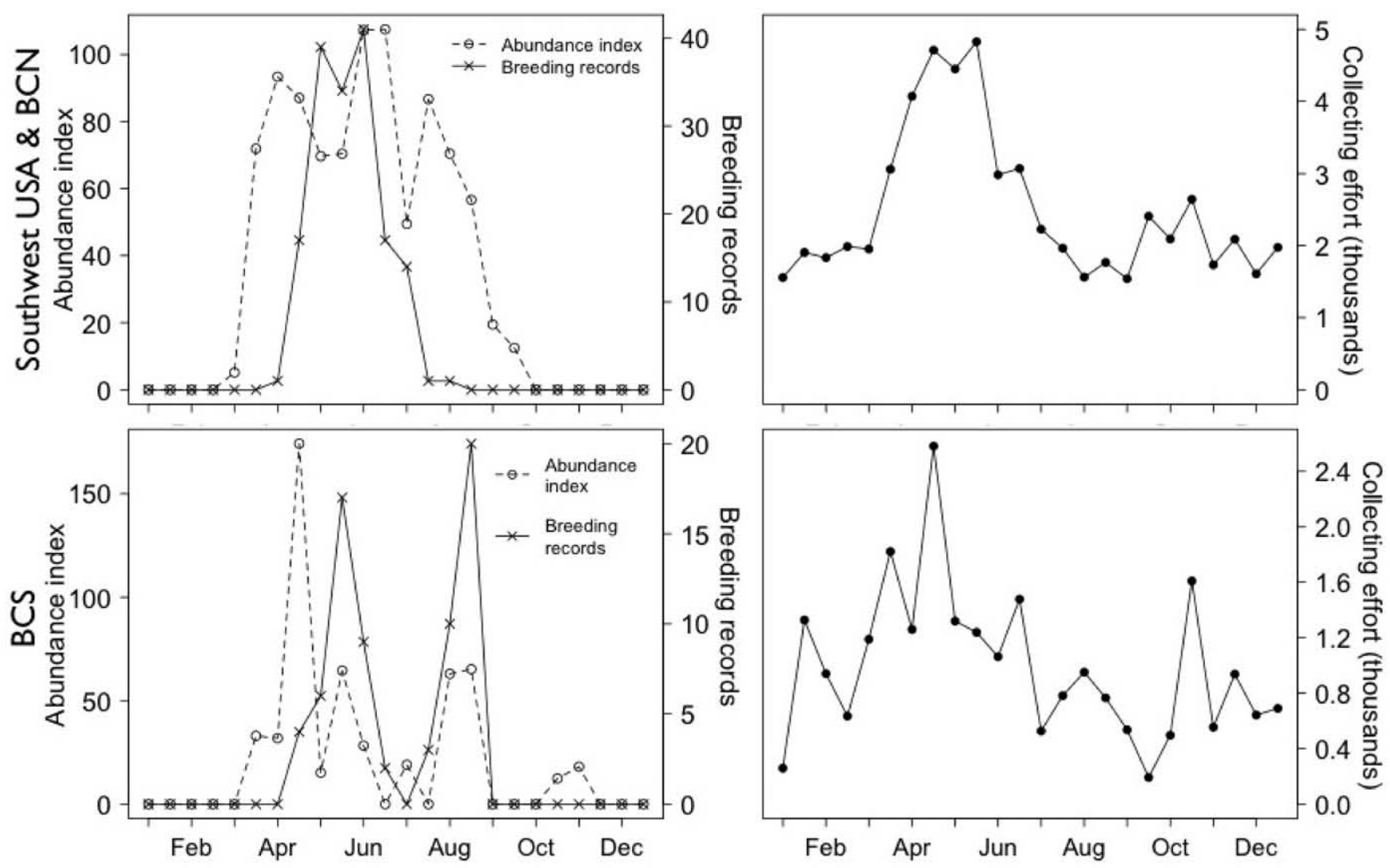

FIGURE 4. Left panels: abundance indices and counts of breeding records of the Hooded Oriole. Right panels: total passerines used to compute the corresponding abundance index. Abundance index and collecting effort included California, Arizona, and Baja California in the north and Baja California Sur in the south.

all chats we collected in Sinaloa belonged to the western population. Therefore we used abundance indices and egg dates of populations breeding west of the Great Plains only for comparison with those breeding in Sinaloa and Sonora and did not consider chats breeding in eastern North America.

Chats are known to breed in Sinaloa and Sonora but not in $\mathrm{BCS}$, although they are reported from higher elevations more than from the coastal regions of Sinaloa where we worked (Miller et al. 1959). For the western U.S. and British Columbia, both the abundance index and the frequency of egg dates show single strong peaks in early May or early June; in late June and July both the abundance of specimens and the frequency of egg sets drop markedly (Fig. 5). Most of the egg sets collected in the west are from Oregon, California, and Arizona, with little evidence of a second peak of nesting that would be expected if second broods were common in the western North America. This result means that adults could easily move to northwestern Mexico to nest again in July and August. Chats molt on their breeding grounds so have been collected in lower relative numbers through late July and August (Fig. 5); many of the birds collected later in the summer are juveniles.

We found chats to be common from mid-June through August in appropriate habitats in coastal Sinaloa, with males frequently singing throughout the night. Although variable, the abundance index for chat skins in collections from these two states generally increases from April through early June (Fig. 5). In late June the relative abundance of skins drops by almost half, but throughout July it is again high in Sonora and Sinaloa. The high abundance index for Sinaloa and Sonora in July and August is a striking contrast with the pattern seen to the north where the chat's abundance index declines sharply in mid June. These complementary patterns could suggest that some northern birds move south to breed again in Mexico; alternatively, the contrast in abundance patterns may mean that breeding seasons in northwestern Mexico and the western U.S. and Canada differ greatly in length. The late-October peak in the relative abundance of chats in northwestern Mexico (Fig. 5) presumably reflects an influx of migrants from the north.

From our June fieldwork in 2010, it seems clear that earlyseason nesting by chats in Sonora and Sinaloa is underrepresented by available data. There were just three egg sets at WFVZ from Sonora and Sinaloa, all collected in the first half of June. Our field work in mid and late June 2010 added 10 more breeding records, one of old nestlings evidently hatched from eggs laid in late May, the others from females with edematous brood patches that presumably were incubating or 

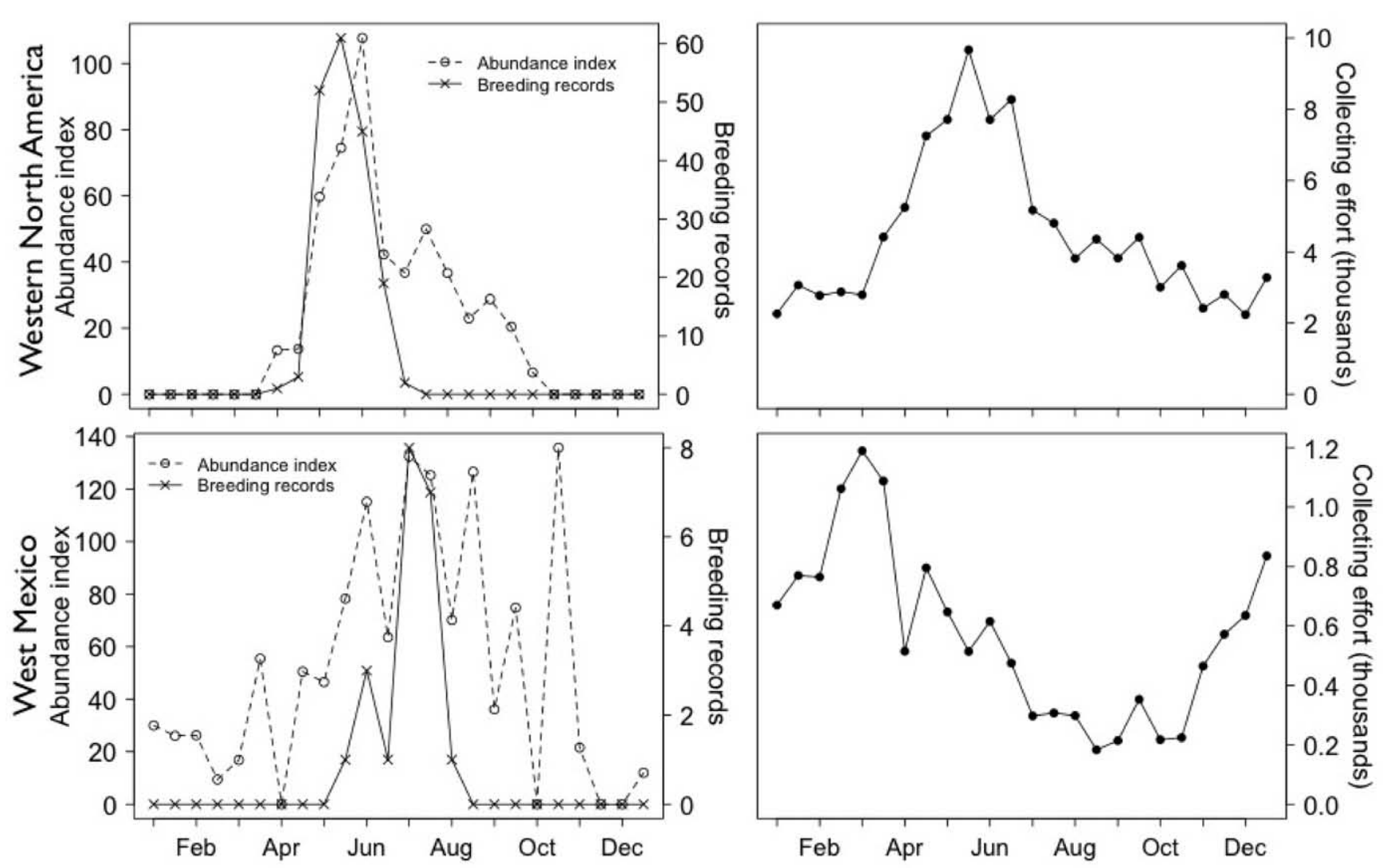

FIGURE 5. Left panels: abundance indices and counts of breeding records of the Yellow-breasted Chat. Right panels: total passerines used to compute the corresponding abundance index. Abundance index and collecting effort included British Columbia and western states of the U.S. in the north and Sinaloa and Sonora for Mexico in the south.

brooding small young. Thus the relative shortage of records of chat nests in Sinaloa and Sonora for late May and June (Fig. 5) seems likely to reflect inadequate field work.

We found 16 egg sets from Baja California (Norte), one collected in late April, all others in May. Chats breed so early in the northern half of the peninsula that these birds have plenty of time to move to Sinaloa and Sonora for a second round of breeding when productivity in the northern part of the peninsula declines with the summer drought (Comrie and Glenn 1998). The chats we collected in Sinaloa in July were in moderately worn plumage, suggesting that, if they are double breeders, they had not molted after breeding in the north, before moving to Sinaloa. Thus, if some chats move south from Baja California or the U.S. to breed again, they must do so before undergoing the annual molt. Otherwise, the breeding birds we collected in early July should have been in completely fresh plumage, as are the migrant chats we catch in September.

\section{CASSIN'S VIREO}

Like the Yellow-breasted Chat, Cassin's Vireo molts in its U.S. and Canadian breeding range (Rohwer et al. 2005, 2008). Thus we were surprised to find individuals in worn plumage singing and apparently breeding at low elevations in the mountains of BCS in August (Rohwer et al. 2009a). If these birds are indeed double breeders from North America, they must be migrating to BCS for their second breeding attempt before undergoing the post-breeding molt. Positing double breeding for this species is further complicated by the fact that an endemic subspecies (V. c. lucasanus) has been described from the mountains of BCS (Brewster 1891, Phillips 1991).

When we obtained our first three specimens of $V$. cassinii from BCS, we shipped tissues from these birds to Kevin Kerr of the barcoding project in Guelph. He compared the sequences of cytochrome $c$ oxidase I from these three specimens with those from 12 of $V$. cassinii from Montana, Oregon, and British Columbia. The three samples from BCS (of which only two voucher skins were at the UWBM) were almost identical in sequence to the 12 birds from the north, suggesting that the birds we found breeding in BCS in August did not represent an endemic subspecies. Furthermore, SR could see no consistent morphological differences between the two BCS birds and Washington breeders. Thus he assumed that the subspecies was invalid and, instead, represents birds from the north breeding again in Mexico.

Vireo c. lucasanus is described as being smaller but having a larger bill than $V . c$. cassinii, having more rounded wings with P9 usually shorter than P5, and having more yellow in its flanks. The UWBM now holds 5 skins from BCS, which 
SR compared with a good series of breeding birds collected in Washington and California. With this larger sample, three or four of the BCS specimens differed from most $V$. cassinii from the United States in having longer bills and more yellow on their flanks, two of the four characters Brewster (1891) used to distinguish this subspecies. This new result suggests that some of specimens examined for stable isotopes (Rohwer et al. 2009a) represented V.c. lucasanus, so the following phenological comparisons may not be appropriate.

Because Cassin's Vireo has only recently been split as a species from the Solitary Vireo, and the nomenclature in some collection databases has not be updated, we excluded skins and egg sets from parts of its range in the U.S. and Canada where $V$. solitarius might occur, including only those from British Columbia, Washington, Oregon, and California. Most egg dates came from California, but good numbers of skins came from the other regions. In the north, the abundance index for Cassin's Vireo peaks in May and June, then drops by half from July through September (Fig. 6), when birds in Washington are molting (Rohwer et al. 2008). The frequency of egg dates has a single sharp peak in the first two weeks of June and drops to near zero during July (Fig. 6). The schedule of Cassin's Vireo breeding in the U.S. and Canada could, therefore, easily accommodate a second breeding in July and August in BCS.

The abundance index for BCS is hard to interpret because birds were not identified to subspecies (Fig. 6). There is an early peak in abundance in late April, which we assume represents spring migrants moving north, but which may also include some specimens of $V$. c. lucasanus. Interestingly, the Atlas of Mexican Bird Distributions database (NavarroSigüenza et al. 2003) contains no May records of $V$. cassini from BCS. Given the difference in bill size and flank coloration we could see in some of the UWBM skins from BCS, the absence of May specimens may simply reflect limited collecting rather than challenge the validity of the resident subspecies, as SR originally assumed. No egg sets from BCS are at the WFVZ, and we found no nests. However, one female we collected in early August was preparing to lay; August males were mated and singing as though breeding, and some had enlarged testes and visible seminal vesicles.

We do not think that too much should be made of the August increase in the relative abundance of Cassin's Vireos in BCS. Without knowing whether they nest there earlier in the summer (as do Hooded Orioles), this peak in relative numbers of skins in collections could simply reflect the commencement of singing associated with a late-summer
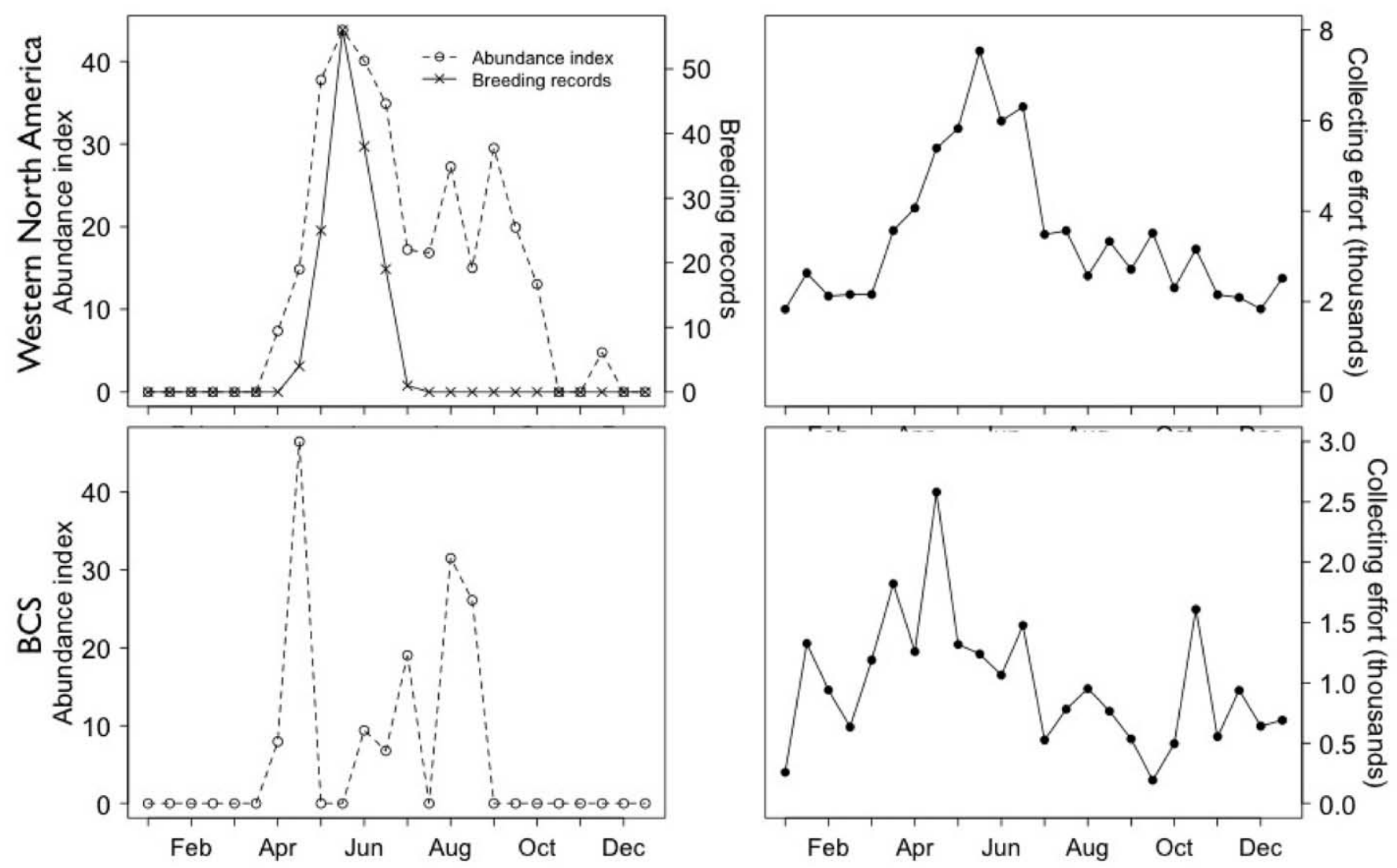

FIGURE 6. Left panels: abundance indices and counts of breeding records of Cassin's Vireo. Right panels: total passerines used to compute the corresponding abundance index. Abundace index and collecting effort included British Columbia, Washington, Oregon, and California in the north and Baja California Sur for Mexico in the south. 
breeding season that coincides with the arrival of the latesummer rains. If this is true, V. c. lucasanus may simply be quiet, rather than absent, during May, particularly if it raises only a single brood, as do northern breeders. This population clearly needs more study to resolve the conflicts between the suggestion of double breeding from isotopes (Rohwer et al. 2009a) and the limited morphological data suggesting that birds sampled by Rohwer et al. (2009a) for isotopes may have been residents.

\section{ISOTOPES AND BAJA CALIFORNIA}

The suggestion that Rohwer et al. (2009a) likely sampled a resident subspecies of $V$. cassinii in Baja California raises the question, "Why did their discriminant analysis classify several of their Cassin's Vireo and Hooded Orioles from Baja California with their sample of known molt migrants, thus suggesting that they were migratory double breeders?" To explore this issue we plotted isotope values against latitude for $\delta^{15} \mathrm{~N}$ and $\delta \mathrm{D}$ from muscle, the two isotope measurements that contributed most strongly to the discrimination of known residents and molt migrants. The plot for $\delta^{15} \mathrm{~N}$ in muscle revealed nothing of interest. However, the plot for $\delta \mathrm{D}$ in muscle, the strongest discriminator in the analysis of Rohwer et al. (2009a), revealed that some Cassin's Vireos and Hooded Orioles from BCS fell within the distribution for molt migrants and beyond the distribution for residents from Sinaloa and BCS. Thus the discriminant analysis classified these individuals as migratory double breeders, but subspecific characters now suggest that several of the Cassin's Vireos so classified may have been members of the local subspecies. Unfortunately, reproductive tissues needed for the stronger analyses of tissue contrasts (Rohwer et al. 2009a) were not saved from these early specimens from BCS because that test had not yet been conceived.

\section{JUNE FIELD WORK}

Of the five species suggested by Rohwer et al. (2009a) to be migratory double breeders, only three breed commonly in Sinaloa: the Yellow-billed Cuckoo, Yellow-breasted Chat, and Orchard Oriole. We were able to assess the abundance of these three species as breeders in June in Sinaloa for the first time in 2010 and found all three species by mid June. Yellowbreasted Chats were as abundant in June as we found them to be in previous years in July and August, suggesting that spring breeding records are underrepresented in our data. In contrast, Yellow-billed Cuckoos appeared to be absent on 9 and 10 June. However, when we conducted playback surveys on 11 June we found them to be present but much less conspicuous than they were in July and August of earlier years. Throughout June and early July 2010 cuckoos called occasionally and continued to respond weakly to playback, but the breeding status of the birds we banded was uncertain. In earlier years they called frequently after the rains began, but rain was sparse in July 2010. Orchard Orioles were also present and breeding in mid June, with the earliest egg date estimated as 28 May. Also, a female captured and banded while feeding nestlings in late June was later seen building a nest in late July, indicating that at least some July breeders are the same as the June breeders.

\section{GENERAL DISCUSSION}

\section{ABUNDANCE INDICES}

Through efficient online access to collection data, we present for the first time an extensive use of total passerines in scientific collections as a measure of collecting effort in space and time. Abundance indices are particularly valuable for showing whether absences of certain categories of specimens results from those birds not being present at the time and place of interest or from lack of collecting (Barry et al. 2009). They also illustrate when a species was collected in numbers beyond the background level of collecting, which we measure as the sum of all other passerines collected in the same region and time period. Online databases of museum specimens represent a useful and largely ignored tool for assessing seasonal movements. If overall collecting effort in a region and time period is indexed appropriately by the number of passerines collected in that region and time period, then specimen counts for a species of interest from the same place and time can be adjusted for effort, giving a reasonable sense of migrants' arrival and departure times. We chose total passerines as our index of collecting effort because the five species studied here are medium-sized land birds commonly taken by collectors working in terrestrial habitats.

Clearly, the denominator in an abundance index needs to represent other birds that collectors would be likely to take when they collect specimens of the species of interest. On a much smaller scale, Barry et al. (2009) showed that using total passerines as a measure of collecting effort gave departure times for adult Western Kingbirds (Tyrannus verticalis) that closely paralleled results obtained when collecting effort was assessed as adult kingbirds divided by the sum of adults and immature kingbirds in collections. That example and the results reported here suggest that using online databases to develop indices of collecting effort can provide useful and often difficult-to-determine information about the timing and location of seasonal movements of migratory species.

\section{PHENOLOGY AND MIGRATORY DOUBLE BREEDING}

Both our abundance indices and our counts of egg dates show displaced phenologies between the U.S. and Canada and northwestern Mexico for some species. These complementary phenologies, in which a species is abundant and breeding in its northern range in spring and then becomes abundant and breeds in northwestern Mexico in late summer, are consistent with migratory double breeding of the Orchard Oriole and Yellow-billed Cuckoo. However, they are equally as consistent with birds in western Mexico simply waiting until the 
onset of the late-summer monsoon to commence breeding, and these explanations cannot be evaluated without better data on the breeding phenology of birds from the tropical deciduous forests of western Mexico.

For the Orchard Oriole, the complementary phenological data seem particularly suggestive simply because this species was largely unknown as a breeder in western Mexico prior to our recent field work (Rohwer et al. 2009a). As for the Orchard Oriole, the scarcity of specimens of the Yellow-billed Cuckoo collected from May and June in western Mexico, and the abundance of specimens and breeding records in July and August (Short 1974, Rohwer et al. 2009a), make the case for migratory double breeding particularly strong. If we assume that second-breeding Yellow-billed Cuckoos in western Mexico originate from birds that bred earlier in eastern North America, instead of western North America, as assumed by Rohwer et al. (2009a), the displaced phenologies are consistent with migratory double breeding. Remarkably, both the abundance-index data and the distributions of egg dates for cuckoos from eastern and western North America suggest that late-breeding cuckoos in the western U.S. may also be migratory double breeders from eastern North America. If true, this hypothesis would resolve the long-puzzling observation that western cuckoos breed much later than eastern cuckoos (Hamilton and Hamilton 1965, Franzreb and Laymon 1993).

For the Hooded Oriole the case for double breeding based on displaced phenologies is less strong because this species breeds in northwestern Mexico (Miller et al. 1959), abundantly in May and June in BCS (Fig. 4). However, the extent of late-summer breeding that we have observed in BCS seems to have been previously unappreciated, and our data do not adequately reflect the numbers of Hooded Orioles nesting in July and August in BCS because we were not working in towns, where the species is especially abundant. Thus it is still possible that some late-summer breeders in northwestern Mexico are second breeders from the north that have moved south to exploit the late-summer rains. For the Hooded Oriole, knowing the age composition of birds collected in the U.S. in late summer would be particularly informative. If most birds that linger in the north through July and August (Fig. 4) prove to be young of the year, the phenological case for migratory double breeding would be stronger.

For the Yellow-breasted Chat and Cassin's Vireo, the phenological evidence for migratory double breeding is inconclusive; furthermore, both species were previously known to breed in northwestern Mexico (Miller 1941). For the chat the abundance index for northwestern Mexico remains high from late May through August, when singing males are abundant. Rather than migratory double breeding the phenology data suggest a breeding season much longer in northwestern Mexico than in the western U.S. and Canada. The picture for Cassin's Vireo does show a displaced phenology, but our new comparison of the subspecific characters based on five specimens suggests that the birds used in the isotope study may have been of the subspecies resident in BCS. The low numbers of Cassin's Vireo specimens from May and June shown by the abundance index could be explained by quiet, nonbreeding behavior prior to the summer rains.

\section{MOLT SCHEDULING AND MIGRATORY DOUBLE BREEDING}

Interestingly, the scheduling of these five species' molt matches our confidence in their being double breeders based on the new data provided in this paper. The case seems strongest for the Orchard Oriole, Yellow-billed Cuckoo, and, to a lesser extent, Hooded Oriole, all of which delay molting until after their fall migration. If some Yellow-breasted Chats and Cassin's Vireos are migratory double breeders, then the specimens from northwestern Mexico suggest that, if individuals move there from the north to breed again, they do so before molting because both species molt on their northern breeding grounds (Rohwer et al. 2005, 2008). While this sort of flexibility in the scheduling of molt and migration may occur, we are unaware of such variation having been documented within a population. If birds move between isoscapes that are sufficiently different, such a strategy might be addressed by looking for evidence of a bimodal distribution of stable-isotope values from feathers sampled from northern breeding populations. Feathers from chats and Cassin's Vireos that moved south to breed again before molting should carry a southern signature, while feathers from birds that molted in the north should carry a northern signature.

\section{COMPARISONS WITH OTHER SPECIES}

On the basis of complementary changes in abundance in different regions, two Eurasian species have been suggested to breed twice as they migrate north. The Common Quail (Coturnix coturnix) breeds early in North Africa, then drops in numbers there as it arrives on the Italian Peninsula and spreads north and west across Europe as far as Britain (Moreau 1951). In this case changes in reports of arrival and departure seem to constitute the basis of its status as a migratory double breeder; so far as we know, no evidence based on stable isotopes or on abundance indices has been used to confirm the status of the Common Quail as a migrant that breeds more than once as it moves north. The Eurasian Dotterel (Charadrius morinellus) is also reported to breed first in Scotland and later in the same summer in Scandinavia. While few details have yet been published on this case (Whitfield in Wernham et al. 2002), the principal evidence is sexratio changes between the two regions. Such data are more convincing because changes in the percentage of males in a population represent a correction for sampling effort. Again, independent evidence from stable isotopes has not been presented for this species, though the relatively short distance it moves may preclude the use of isotopes (Whitfield in Wernham et al. 2002). 
Other species reported to breed at different places in the same season differ from migratory double breeders because they generally are not long-distance, nocturnal migrants, and they are often species that exploit irruptive food sources (Newton 2008). An often-cited case is the Phainopepla (Phainopepla nitens), which breeds in late winter in the Sonoran Desert of Arizona and California and then apparently moves to the oak and sycamore canyons of California and Arizona where it breeds later. In the desert it is dependent on mistletoe fruits and territorial, but in woodlands it breeds in loose colonies because fruit production is ephemeral. While many have speculated that the same individuals bred in both locations, convincing evidence for double breeding by the same individuals remains elusive (Chu and Walsberg 1999) Because females' oviducts always regress between clutches, the Phainopepla is a species for which contrasts in isotopes between muscle and oviduct tissue from laying females collected in the oak-sycamore habitats of their presumed second breeding locality should be particularly informative (Rohwer et al. 2009a).

\section{ACKNOWLEDGMENTS}

Thanks to David Giblin for plant identification and to Rob Faucett, Chris Wood, Marco Ortiz, Samuel López, Erick García, Jaime Castro, Jessie Barry, Gabriel David, Sara Zakutansky, Brigitte Rohwer, and Michael Donahue for help with expeditions. Thanks to René Corado at the Western Foundation of Vertebrate Zoology for generating electronic files of its egg sets of the species we treat. Kevin Kerr and the staff at the Biodiversity Institute of Ontario provided the COI sequences for Cassin's Vireo, and J. V. Remsen and R. Hernandez helped find a reference. Our field work in northwestern Mexico was supported by the Burke Museum Endowment for Ornithology and by grants from Hugh S. Ferguson, the Nuttall Ornithological Club, and region 6 of the U.S. Fish and Wildlife Service. Thanks to Stephanie Jones for helping arrange the region 6 grant. Collecting for this project was conducted under scientific collector permits issued by the Secretaría de Medio Ambiente y Recursos Naturales (SEMARNAT) to the Facultad de Ciencias (B. Hernández-Baños FAUT 0169) of the Universidad Nacional Autónoma de México (UNAM).

Institutions providing data from which we computed abundance indices for the five species of interest were the American Museum of Natural History, New York; Academy of Natural Sciences of Philadelphia; Bell Museum of Natural History, University of Minnesota; Museum für Naturkunde, Zentralinstitut der Humboldt-Universität zu Berlin; Natural History Museum, Tring, England; Zoologische Forschungsinstitut und Museum Alexander Koenig, Bonn; Übersee-Museum Bremen; Carnegie Museum of Natural History, Pittsburgh; California Academy of Sciences, San Francisco; Canadian Museum of Nature, Ottawa; Colección Ornitológica, Centro de Investigaciones Biológicas, Universidad Autónoma de Morelos; Cornell University Museum of Vertebrates, Ithaca, New York; Denver Museum of Natural History; Delaware Museum of Natural History, Greenville; Department of Zoology, Manchester Museum, Manchester, England; Museo de Zoología, Facultad de Estudios Superiores Zaragoza, UNAM, México; Fort Hays State College, Hays, KS; Field Museum of Natural History, Chicago; Senckenberg Museum, Frankfurt; Museo Civico di Storia Naturale Giacomo Doria, Genoa; Colección Nacional de
Aves, Instituto de Biología, UNAM; University of Kansas Natural History Museum, Lawrence; Los Angeles County Museum of Natural History; Natuurhistorische Museum, Leiden; Louisiana State University Museum of Natural Sciences, Baton Rouge; Museo de las Aves de México, Saltillo; Museo de la Biodiversidad Maya, Universidad Autónoma de Campeche, Campeche; Museum of Comparative Zoology, Harvard University, Cambridge, MA; Museum d'Histoire Naturelle, Geneva; Moore Laboratory of Zoology, Occidental College, Los Angeles; Michigan State University, East Lansing; Museo Nacional de Ciencias Naturales, Madrid; Muséum Nationale d'Histoire Naturelle, Paris; Zoological Museum Moscow State University; Museum Mensch und Natur, Munich; Museum of Vertebrate Zoology, University of California, Berkeley; Museo de Zoología, Facultad de Ciencias, UNAM; University of Nebraska, Lincoln; Naturhistorische Museum Wien, Vienna; Royal Ontario Museum, Toronto; San Diego Natural History Museum; Staatliches Museem für Naturkunde, Stuttgart; Texas Cooperative Wildlife Collections, Texas A\&M University, College Station; Universidad Autónoma de Baja California, Ensenada; University of Arizona, Tucson; University of British Columbia Museum of Zoology, Vancouver; University of California, Los Angeles; Florida Museum of Natural History, Gainesville; University of Michigan Museum of Zoology, Ann Arbor; Universidad Michoacana de San Nicolás de Hidalgo, Morelia; University Museum of Zoology, University of Cambridge, Cambridge, England; United States National Museum of Natural History, Washington, D.C.; University of Washington Burke Museum, Seattle; Western Foundation of Vertebrate Zoology, Camarillo, CA; Peabody Museum, Yale University, New Haven; and the database of the Sistema Nacional de Información de Biodiversidad, Comisión Nacional para el Conocimiento y Uso de la Biodiversidad (CONABIO), México.

\section{LITERATURE CITED}

Adams, D. K., And A. C. Comrie. 1997. The North American monsoon. Bulletin of the American Meterological Society 78:2197-2213.

Barry, J. H., L. K. Butler, S. Rohwer, And V. G. Rohwer. 2009. Documenting molt-migration in Western Kingbird (Tyrannus verticalis) using two measures of collecting effort. Auk 126:260-267.

Brewster, W. 1891. Descriptions of seven supposed new North American birds. Auk 8:139-149.

Chu, M., And G. WAlsberg. 1999. Phainopepla (Phainopepla nitens), no. 415. In A. Poole and F. Gill [EDS.], The birds of North America. Birds of North America, Inc., Philadelphia.

Comrie, A. C., And E. C. Glenn. 1998. Principal componentsbased regionalization of precipitation regimes across the southwest United States and northern Mexico, with an application to monsoon precipitation variability. Climate Research 10:201-215.

Dickerman, R. W., AND D. W. WARnER. 1962. A new Orchard Oriole from Mexico. Condor 64:311-314.

Franzreb, K. E., And S. A. LAYMON. 1993. A reassessment of the taxonomic status of the Yellow-billed Cuckoo. Western Birds 24:17-28.

GaINES, D., AND S. A. LAYMON. 1984. Decline, status and preservation of the Yellow-billed Cuckoo in California. Western Birds 15:49-80.

Hamilton, W. J. III, AND M. E. Hamilton. 1965. Breeding characteristics of Yellow-billed Cuckoos in Arizona. Proceedings of the California Academy of Sciences 32:405-432.

Hughes, J. M. 1999. Yellow-billed Cuckoo (Coccyzus americanus), no 418. In A. Poole and F. Gill [EDS.], The birds of North America Online. Birds of North America, Inc., Philadelphia. 
Laymon, S., ANd M. D. Halterman. 1987. Can the western subspecies of the Yellow-billed Cuckoo be saved from extinction? Western Birds 18:19-25.

Miller, A. H., H. Friedmann, L. Griscom, and R. T. Moore. 1959. Distributional check-list of the birds of Mexico. Part II. Pacific Coast Avifauna 33.

Moreau, R. E. 1951. The British status of the quail and some problems of its biology. British Birds 44:257-276.

Navarro S., A. G., A. T. Peterson, and A. Gordillo-Martinez. 2003. Museums working together: the atlas of the birds of Mexico. In N. Collar, C. Fisher, and C. Feare [EDS.], Why museums matter: avian archives in an age of extinction. Bulletin of the British Ornithologists' Club Supplement 123A:207-225.

Newton, I. 2008. The migration ecology of birds. Elsevier, London.

Pearson, S. F., AND S. Rohwer. 1998. Determining clutch size and laying dates using ovarian follicles. Journal of Field Ornithology 69:587-594.

Peterson, A. T., A. G. Navarro-Sigüenza, and H. Benítez-Díaz. 1998. The need for continued scientific collecting: a geographic analysis of Mexican bird specimens. Ibis 140:288-294.

Phillips, A. R. 1991. The known birds of North and Middle America, part II. A. R. Phillips, Denver.

Pleasants, B. Y., And D. J. Albano. 2001. Hooded Oriole (Icterus cucullatus), no. 568. In A. Poole and F. Gill [EDS.], The birds of North America. Birds of North America, Inc., Philadelphia.

Pruett, C. L., D. D. Gibson, And K. Winker. 2001. Molecular "cuckoo clock" suggests listing of western Yellow-billed Cuckoos may be warranted. Wilson Bulletin 113:228-231.

Rohwer, S., L. K. Butler, and D. R. Froehlich. 2005. Ecology and demography of east-west differences in molt scheduling in neotropical migrant passerines, p. 87-105. In R. Greenberg and P. P. Marra [EDS.], Birds of two worlds. Johns Hopkins University Press, Baltimore.
Rohwer, S., K. A. Hobson, And V. G. Rohwer. 2009a. Migratory double breeding in neotropical migrant birds. Proceedings of the National Academy of Sciences U.S.A. 106:19050-19055.

Rohwer, S., K. A. Hobson, And V. G. Rohwer. 2010. Reply to Urquhart: conservation of migratory double breeders. Proceedings of the National Academy of Sciences U.S.A. 107:E16.

Rohwer, S., A. G. Navarro, AND G. VoelKer. 2007. Rates versus counts: fall molts of Lucy's Warblers (Vermivora luciae). Auk 124:806-814.

Rohwer, V. G., S. Rohwer, AND J. H. BArry. 2008. Molt scheduling of western neotropical migrants and up-slope movement of Cassin's Vireo. Condor 110:365-370.

Rohwer, V. G., S. Rohwer, AND M. F. Ortiz-Ramirez. 2009b. Molt biology of resident and migrant birds of the monsoon region of west Mexico. Ornitología Neotropical 20:565-584.

SAuer, J. R., J. E. Hines, AND J. FAllon. 2008. The North American Breeding Bird Survey, results and analyses 1966-2007. Version 5.15.2008. USGS Patuxent Wildlife Research Center, Laurel, MD.

SCHARF, W. C., AND J. KREN. 1996. Orchard Oriole (Icterus spurius), no. 255. In A. Poole and F. Gill [EDS.], The birds of North America. Academy of Natural Sciences, Philadelphia.

Schondube, J. E., E. Santa C., And I. Ruán-Tejeda. 2003. Biannual cycles of the Cinnamon-bellied Flowerpiercer. Biotropica $35: 250-261$.

SHORT, L. L. 1974. Nesting of southern Sonoran birds during the summer rainy season. Condor 76:21-32.

Sibley, D. A. 2000. The Sibley guide to birds. Knopf, New York.

Stutchbury, B. J. M., S. A. Tarof, T. Done, E. Gow, P. M. Kramer, J. TAUtin, J. W. FoX, AND V. AfANASYEV. 2009. Tracking long-distance songbird migration by using geolocators. Science 323:896.

Wernham, C. V., M. P. Toms, J. H. Marchant, J. K. Clark, G. M. Siriwardena, AND S. R. BAILlie. 2002. The migration atlas: movements of the birds of Britain and Ireland. T. \& A. D. Poyser, London. 